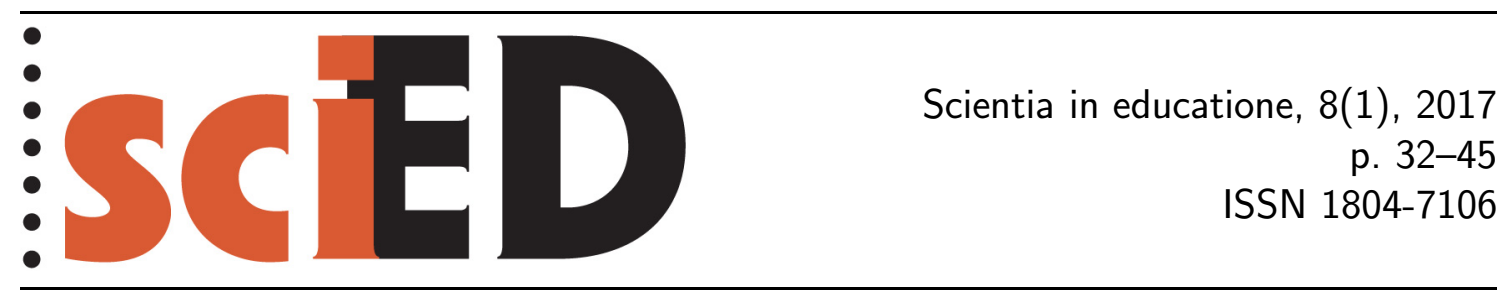

\title{
Hodnocení efektivity badatelsky orientovaného vyučování v laboratorních pracích při výuce fyziologie člověka na základní škole a nižším stupni gymnázia
}

\author{
Lukáš Rokos, Vladislava Vomáčková
}

\begin{abstract}
Abstrakt
Hlavním cílem tohoto výzkumu bylo porovnání efektivity badatelsky orientované výuky (IBSE) a klasických laboratorních prací, při kterých žáci pracují podle návodu od učitele, $\mathrm{v}$ rámci vybraných témat $\mathrm{z}$ fyziologie člověka. Tento př́spěvek prezentuje výsledky studie sledující vliv IBSE na znalosti a dovednosti žáků na základní škole a žáků nižšího cyklu víceletého gymnázia. $\mathrm{K}$ měření úrovně znalostí a dovedností byl použit pretest a dva posttesty. Byl zjištěn statisticky průkazný efekt typu výuky u žáků gymnázia na rozdíl od žáků na základní škole. IBSE mělo pozitivní vliv u žáků nižšího cyklu osmiletého gymnázia, kteří se signifikantně zlepšili zejména v dovednostní části testu.
\end{abstract}

Klíčová slova: badatelsky orientované vyučování, výuka přírodopisu a biologie.

\section{Efficacy of Inquiry-based Science Laboratory Work in Human Physiology Lesson at Lower Secondary Level and Lower Cycle of Grammar School}

\begin{abstract}
The main aim of this study was a comparison of inquiry-based science education (IBSE) and traditional science lab courses where students perform selected human physiology assignments listed in a manual they have received from the teacher. This paper presents the results of a study assessing IBSE impact on the students' knowledge and skills acquisition of lower secondary school pupils and students at grammar school lower cycle. One pre-test and two post-tests were administered in order to assess and compare the respective levels of their knowledge and skills. The results of the grammar school lower cycle students indicated a statistically significant improvement, unlike those of the lower secondary level pupils. IBSE had demonstrably positive impact on the grammar school students, particularly in the skill-oriented part of the tests.
\end{abstract}

Key words: inquiry-based education, integrated science and biology education. 


\section{EFEKTIVITA VE VZDĚLÁVACÍM PROCESU}

Efektivita vzdělávacího procesu je velice aktuálním tématem současných pedagogických výzkumů. Na sledování efektivity vzdělávacího procesu se začali soustředit autoři již v 80. letech (např. Kulič, 1980). Průcha (1996) ve své monografii vymezil efektivitu z pohledu různých oborů a zaměřil se také na srovnání pojmů efektivita a kvalita. V tomto př́ipadě uvádí, že význam těchto pojmů není zcela přesně vymezen a často se překrývá, což potvrzují i Starý a Chvál (2009), kteří dodávají, že v pedagogické sféře jsou tyto pojmy často zaměňovány. Efektivita by měla být chápána jako obecné vyjádření vztahu mezi nějakým výsledkem a tím, co vedlo k tomuto výsledku, co jej zapříčinilo či ovlivnilo (Starý \& Chvál, 2009). V procesu výuky je výsledek představován určitými výstupy (např. žákovými znalostmi či dovednostmi).

Dále tito autoři uvádějí, že většina výzkumů zaměřených na efektivitu výuky je kvantitativního typu a až v posledních letech jsou výzkumy doplňovány kvalitativními metodami. Ačkoliv bylo publikováno několik výzkumů a studií na toto téma, jedinou více propracovanou monografii představuje Kvalita (ve) vzdělávání (viz Janík et al., 2013). Průcha (1996) rozdělil výzkumy sledující efektivitu výuky do tří skupin. První skupinou jsou výzkumy zaměřené na reálný efekt výuky a sledující, co se žáci skutečně naučili. Druhou skupinu představují výzkumy, které porovnávají efekt dvou odlišných typů vyučování, a poslední skupinou jsou analytické výzkumy, které objasňují efektivnost i na základě analýzy vlastností a podmínek procesu, který vedl k daným výsledkům.

Scheerens (2004) a Seidelová a Shavelson (2007) provedli syntézu studií zaměřených na efektivitu výuky v různých státech a zjistili, že v těchto výzkumech byly identifikovány některé nové trendy, na které je vhodné se zaměřit v dalších studiích. Jeden z trendů představovalo i zaměření se na vhodnost aktivního zapojení žáků do procesu učení a užití moderních učebních strategií. Právě soustředění se na efektivitu vybraných metod výuky představuje aktuální trend v pedagogickém výzkumu. Ve výzkumech je efektivita určována z dopadu na úroveň osvojených znalostí či dovedností nebo rozvoje poznávacích schopností žáků (Kulič, 1980), ale je sledován i vliv dalších faktorů, které mohou efektivitu ovlivnit, např́iklad užití učebních pomůcek, vliv motivace žáků či organizace výukové jednotky (Einsiedler, 2000; Petty, 2006).

Průcha (1996) uvádí dva typy hodnocení efektivity. První metodou je hodnocení efektivnosti na základě výpovědí posuzovatelů. K zisku dat se v tomto př́padě používají např́klad rozhovory se žáky či učiteli nebo dotazníková šetření s využitím různých posuzovacích škál, pozorování a analýzy výuky či pedagogické dokumentace. Druhým typem je hodnocení efektivnosti vzdělávacího procesu z jeho produktů. Průcha (1996) rozumí „produktem“ výsledky učení (at již okamžité či dlouhodobé), které se projevují změnami v úrovni vědomostí, dovedností či postojů a názorů. Využívaným nástrojem jsou v tomto př́ípadě didaktické testy, např́iklad různé typy pretestů zadaných před samotnou výukou a posttestů zadaných po ukončení výuky. Následné porovnání výsledků v obou zmíněných testech poskytuje základní data pro posouzení efektivity dané výukové metody. 


\section{BADATELSKY ORIENTOVANÉ VYUČOVÁNÍ V Př́́RODOPISU A BIOLOGII}

Konstruktivistické metody výuky jsou moderním trendem ve výuce přírodovědných předmětů. Badatelsky orientované vyučování (IBSE, z anglického inquiry based science education) představuje konkrétní př́klad konstruktivistické metody a možnou cestu zásadní inovace přrírodovědného vzdělávání (Rocard et al., 2007). V Ceské republice probíhají již šest let pokusy o efektivní implementaci badatelsky orientovaného vyučování do výuky př́rodopisu na základní škole a biologie na střední škole (Petr et al., 2015). Prvky IBSE jsou v přírodovědných předmětech zahrnovány nejčastěji do praktických činností a laboratorních prací. Vzhledem k tomuto trendu je problematika badatelsky orientovaného vyučování stále aktuální a existuje spousta výzkumů, které se jím v českém edukačním prostředí zabývají.

„Bádání“ vymezuje Anderson (2002) jako aktivitu, při které se žáci aktivně zapojují do procesu vlastního vzdělávání prostřednictvím kladení a formulování výzkumných otázek, popř. hypotéz, hledání relevantních zdrojů informací, samostatného vedení pozorování nebo experimentů, shromaždování dat a jejich interpretace. Součástí IBSE jsou operace s problémy a aplikace zjištěných výsledků do každodenního života. Johnson (2009) dodává, že cílem úloh s prvky IBSE je aktivní zapojení žáka do procesu bádání. Dalším charakteristickým prvkem IBSE je vyšší autonomie žáka a učitel je spíše v roli poradce (Papáček, 2010; Nezvalová, 2010). Podle míry autonomie žáka a intenzity vstupů ze strany učitele při řešení úlohy je možné rozlišit čtyři úrovně IBSE (Eastwell, 2009; Bell, Smetana \& Binns, 2005; Stuchlíková, 2010): potvrzující, strukturované, nasměrované a otevřené bádání, které představuje nejvyšší úroveň, kdy žáci samostatně identifikují problém, formulují výzkumnou otázku a hypotézu, navrhnou vlastní pokus, provedou sběr dat, jejich interpretaci a stanoví závěry včetně potvrzení či vyvrácení původní hypotézy (Stuchlíková, 2010).

Jako každý nový přístup má i IBSE své klady a zápory. Zejména časová náročnost a potřeba příslušného vybavení při těchto úlohách představuje významný limitující faktor (Papáček, 2010; ProCoNet, 2011). Další výraznou překážkou je fakt, že samotní učitelé i žáci se $\mathrm{v}$ tomto přístupu cítí nejistě z důvodu nedostatečných zkušeností, což může negativně ovlivnit zejména výsledky žáků a následně i důvěru učitelů v tento přístup (Bhattacharyya, Volk \& Lumpe, 2009; Stavik-Karlsen \& Grey, 2013). Toto potvrzuje výzkum Petra et al. (2015), jehož výsledky ukazují, že ani po dlouhodobé snaze o postupné zavádění a propagování IBSE v České republice mnoha aktérům vzdělávání stále není zcela jasný jeho hlavní princip. Ve většině případů je badatelsky orientované vyučování (IBSE) chápáno jako vyučovací metoda založena zejména na provádění pokusů a pozorování.

Při samotném výběru badatelského úkolu je dle Petra (2014) nutné přihlédnout $\mathrm{k}$ několika důležitým aspektům (obsah úlohy, vztah k rozvíjeným kompetencím, časové dispozice a materiální požadavky). Při aplikaci IBSE by měl být kladen důraz na úlohy, které jsou jednoduché a nenáročné, ale zároveň budou rozvíjet základní složky vědeckého myšlení. Petr (2014) rozděluje badatelské úlohy do třech základních skupin. První skupinu představují jednoduché experimenty, při kterých žáci sledují vliv jedné nezávislé proměnné na jinou závislou proměnnou (např. vliv světla na růst rostlin). Druhou skupinou jsou jednoduchá pozorování, kdy žáci pečlivě pozorují a popisují daný objekt (např. mikroskopování). Poslední skupinou jsou jednoduché př́klady, které sledují určitý proces a žáci si jimi ověřují teoretické vědomosti. V tomto případě se př́imo nejedná o klasické bádání, ale pouze o užití některých jeho 
prvků, jelikož žáci při této aktivitě nemají odpovídající volnost, která je považována za jeden z hlavních atributů otevřeného bádání.

\section{VÝZKUMY ZAMĚŘENÉ NA IBSE}

Výzkumů, které by se zabývaly efektivitou badatelsky orientovaného vyučování, je však v českých podmínkách poskrovnu. První výzkumy či sondy se zabývaly zejména limity pro implementaci tohoto přístupu do vyučování (cf Papáček, 2010) nebo teoretickým vymezením jednotlivých stupňủ bádání (cf Stuchlíková, 2010). Dostál (2013) zmiňuje zcela zásadní obecnou otázku, zda je IBSE efektivní. Efektivitou IBSE v závislosti na typu motivace žáka se zabývali Škoda et al. (2015), kteří provedli studii u 15 letých studentů na vybraných českých středních školách. Při tomto výzkumu testovali jejich znalosti před zahájením výzkumu, poté ihned po jeho ukončení a následně s odstupem čtyř měsíců ještě jednou. Výsledky potvrdily, že motivace je jedním z klíčových faktorů pro efektivitu IBSE. Zároveň bylo prokázáno, že se efektivita IBSE lišila u jednotlivých typů vnitřní motivace. Efektivitou IBSE se dále zabývali Vácha a Ditrich (2016) na nižšśm stupni základní školy a autorky Ryplová a Reháková (2011) na vyšším stupni základní školy.

$\mathrm{V}$ zahraničí je účinnost IBSE často diskutovaným tématem nejen $\mathrm{v}$ akademických kruzích, mezi pedagogy, ale u širší veřejnosti. Educational Development Center (2007) uvádí, že existuje několik studií, které srovnávají IBSE oproti jinému způsobu výuky. Často však chybí kontrolní skupina nebo je výuka v této skupině nejasně definována jako „tradiční výuka“ bez bližší specifikace (Educational Development Center, 2007), tudíž jsou výsledky těchto studií často neprůkazné. Minner, Levy a Century (2010) provedli syntézu výzkumů zaměřených na IBSE v prŕrodovědném vzdělávání a zjistili, že polovina ze 138 sledovaných studií vykazovala pozitivní impakt IBSE na proces učení žáků a zapamatování si nových informací. Ve 42 srovnávacích studiích bylo zjištěno, že více než polovina žáků ve skupinách s větším podílem IBSE vykazovala signifikantně lepší výsledky než žáci ze skupiny s menším či žádným podílem IBSE.

Př́́kladem výzkumu, který srovnává experimentální skupinu s IBSE a kontrolní s klasickou transmisivní výukou, je studie Coberna et al. (2010), ve které byl sledováno, zda výuka s prvky IBSE vede k lepšímu porozumění obsahu jako klasická frontální výuka s návodem od učitele. Během 2 týdenního programu na střední škole nebyl zjištěn signifikantní rozdíl mezi experimentální a kontrolní skupinou. Celkem byly sledovány jen dva tematické celky, takže není možné zjištěné závěry zcela generalizovat ve vztahu $\mathrm{k}$ dalším tématům. Jak uvádí autoři studie, téma a znění témat mohou mít vliv na to, zda je daná výuka efektivní (Cobern et al., 2010). Autoři se zaměřili i na porovnání doby zpracování úlohy, kde se ukázalo, že studenti z kontrolní skupiny pracovali přibližně o 5 až 10 minut kratší dobu než studenti z experimentální skupiny. Tento výsledek může být zkreslený faktem, že studenti z experimentální skupiny neměli žádné zkušenosti s badatelskou výukou, takže se v daných úkolech museli nejdříve zorientovat (Cobern et al., 2010).

Další výzkumy byly provedeny zejména v asijském edukačním prostředí. Chang a Mao (1999) porovnávali efektivitu mezi IBSE a tradičními výukovými metodami na střední škole a srovnával výsledky a přístupy $\mathrm{k}$ př́rodovědným předmětům na Taiwanu. Celkem bylo do výzkumu zapojeno 16 skupin studentů a po provedení analýzy bylo zjištěno, že experimentální skupina (pracující s prvky IBSE) dosáhla signifikantně lepšího skóre než studenti z kontrolní skupiny. Také bylo zjištěno, že IBSE následně vedlo $\mathrm{k}$ lepšímu postoji $\mathrm{k}$ přírodovědným předmětům. 
Bunterm et al. (2014) srovnávali efektivitu jednotlivých stupňů IBSE. Sledovali nasměrované a strukturované bádání při výuce přírodovědných předmětů na střední škole v Thajsku. Bylo prokázáno, že studenti ve skupině s nasměrovaným bádáním dosáhli lepších výsledků ve vztahu k porozumění obsahu i k badatelským dovednostem.

\section{CÍl VÝZKUMU}

Hlavním cílem tohoto výzkumu je porovnat efektivitu badatelsky orientovaných úloh a klasických laboratorních úloh, při kterých žáci pracují podle návodu od učitele, implementovaných do výuky fyziologie člověka na vyšším stupni základní školy a nižším stupni víceletých gymnázií. Celkem byly formulovány tři výzkumné otázky: 1) Vede IBSE k lepšímu osvojení znalostí a dovedností než tradiční výuka?, 2) Existuje rozdíl v efektivitě IBSE z hlediska osvojení znalostí a dovedností u žáků na vyšším stupni základní školy a žáků nižšího cyklu osmiletého gymnázia?, 3) Existuje rozdíl mezi znalostní a dovedností částí testu, tzn. vede IBSE k lepšímu osvojení znalostí, dovedností či obou?

Tato studie je součástí rozsáhlejšího výzkumu, který sleduje efektivitu IBSE ve výuce fyziologie člověka na gymnáziu a při vybraných kurzech pro vysokoškolské studenty. Výsledky celého výzkumu by měly být srovnány s výzkumy provedenými v zahraničí (např. Cobern et al., 2010; Chang \& Mao, 1999; Bunterm et al., 2014).

\section{METODIKA}

\section{DESIGN VÝZKUMU}

Výzkum byl proveden na dvou základních školách (v osmém ročníku) a jednom osmiletém gymnázium (v tercii). Výuka byla realizována v březnu a dubnu 2015. Celkem se do průzkumu zapojilo 61 žáků (30 dívek a 31 chlapců), kteří byly rozděleni do experimentální (36 žáků) a kontrolní skupiny (25 žáků) na základě dostupného výběru odpovídajícího rozdělení žáků do skupin na laboratorní cvičení. Věk žáků se pohyboval od třinácti do patnácti let. Experimentální skupina pracovala badatelským př́istupem, kdy si žáci museli navrhnout vlastní pokus, vyhodnotit výsledky, diskutovat je a zapsat závěr. Kontrolní skupina pracovala podle návodu od učitele, kde byly uvedeny jednotlivé kroky postupu práce.

V rámci výzkumu byly vytvořeny úlohy na 3 tematické celky z fyziologie člověka a byly implementovány do výuky 8. ročníku na základní škole a tercie osmiletého gymnázia. Experimentální výuka byla realizována v rozmezí tř́i týdnů a jednotlivé úlohy se věnovaly následujícím tématům: 1) Liší se tepová frekvence sportovců a nesportovců?, 2) Máme všichni stejnou vitální kapacitu plic?, 3) Kdo má silnější stisk ruky, praváci nebo leváci? Aby nedošlo k ovlivnění výzkumu přístupem vyučujícího, byly všechny skupiny vyučovány výzkumníky.

\section{Pretest A POSTTESTy}

Pro porovnání efektivity IBSE byly vytvořeny pretesty a posttesty. Pretest dostali žáci před zahájením samotného výzkumu. První posttest žáci vyplňovali vždy přibližně 14 dní po ukončení experimentální výuky. Pro objasnění, zda došlo k dlouhodobému efektu, byl stejný posttest zadán v únoru 2016 (tedy s odstupem 10-11 mě- 
síců po experimentální výuce). Všechny testy obsahovaly osm položek, které se zaměřovaly na znalosti žáků a jejich badatelské dovednosti (např. interpretaci dat, návrh vlastního pokusu nebo stanovení vlastní domněnky/hypotézy). V úvodu testu byly položky zaměřené na demografické údaje o žákovi (křestní jméno, pohlaví, věk, ročník). Otázky vztahující se $\mathrm{k}$ badatelským dovednostem žáků byly vždy otevřeného typu, např. vyslovení domněnky/hypotézy k uvedeným datům, interpretace dat uvedených v tabulce apod. Naopak otázky zaměřené na znalosti žáků byly uzavřené a výběrového typu. Otázky v pretestu a posttestech byly podobné či zcela identické a zaměřovaly se vždy na tematiku, která se vztahovala k realizovaným úlohám. Maximální bodový zisk činil 19 bodů. Z důvodu rozdílné náročnosti znalostních a dovednostních otázek bylo bodové ohodnocení jednotlivých položek odlišné. V př́ípadě správné odpovědi obdrželi žáci u znalostních otázek jeden bod, zatímco u otázek zaměřených na dovednosti šest bodů. Pro jemnější stratifikaci bodového zisku byla stanovena kritéria, dle kterých byly body přidělovány - např. v př́ípadě výše zmíněné položky zaměřené na interpretaci předložených dat, kde měli žáci rozpoznat faktory ovlivňující tepovou frekvenci, dostali: 0 bodů v případě, že nic nenapsali, uvedli nesmyslný závěr či pouze opsali číselné hodnoty z tabulky; 3 body, pokud uvedli alespoň jeden z faktorů, který měl vliv na hodnotu tepové frekvence; 6 bodi̊, pokud identifikovali všechny tři faktory, které byly v tabulce s daty nastíněny.

\section{ZPRACOVÁNÍ A VYHODNOCENÍ DAT}

Získaná data - výsledky z pretestu a obou posttestů - byla analyzována prostřednictvím testu ANOVA opakovaných měření (repeated-measures ANOVA) s typem výuky (IBSE vs. tradiční) jako kategoriální proměnnou. Protože lze předpokládat rozdílné schopnosti či připravenost k IBSE žáků na gymnáziích a na základních školách (cf Banchi \& Bell, 2008), byly výsledků z gymnázií a základních škol analyzovány separátně. U každé skupiny respondentů bylo analyzováno celkové skóre dosažené v testech a sledován rozdíl mezi pretestem a posttesty. Protože však lze přepokládat rozdílný vliv IBSE na znalosti a badatelské dovednosti (cf Mattheis \& Nakayma, 1988; Ketelhut, 2007; Schwartz et al., 2002; Wilson et al., 2010), byl následně ještě zvlášt analyzován bodový zisk ze a) znalostní a b) dovednostní části testu. Hladina významnosti byla stanovena na $\alpha=0,05$; všechny testy byly provedeny v programu Statistica 13 (Dell, Statsoft, Tulsa, OK).

\section{VÝSLEDKY}

\section{ŽÁCI ZÁKLADNÍCH ŠKOL}

Celkový bodový zisk žáků základní školy byl statisticky průkazně závislý na času (opakování testu; $F_{2,70}=18,7 ; p<10^{-6}$ ), vliv typu výuky však statisticky průkazný nebyl $\left(F_{2,70}=0,14 ; p=0,87\right)$. Mezi pretestem a prvním posttestem došlo k signifikantnímu zlepšení bodového zisku ze 7,59 na 11,72, poté došlo k mírnému poklesu na 10,58 bodi̊ (oba typy výuky, obr. 1 ).

Podobný trend byl patrný i z hlediska hodnocení vědomostí - ačkoli mírně vyšší znalosti vykazovali žáci s tradičním typem výuky, rozdíly mezi skupinami žáků byly při různých testech konzistentní a vliv typu výuky tak nebyl průkazný $\left(F_{2,70}=0,75\right.$; $p=0,48)$. Vliv opakování testu byl znovu průkazný $\left(F_{2,70}=5,97 ; p=0,004\right)$, mezi pretestem a posttestem 1 došlo k zvýšení míry znalostí (z 2,89 bodu na 3,69 bodu), poté k mírnému snížení (na 3,28 bodu; oba typy výuky dohromady; obr. 2). 


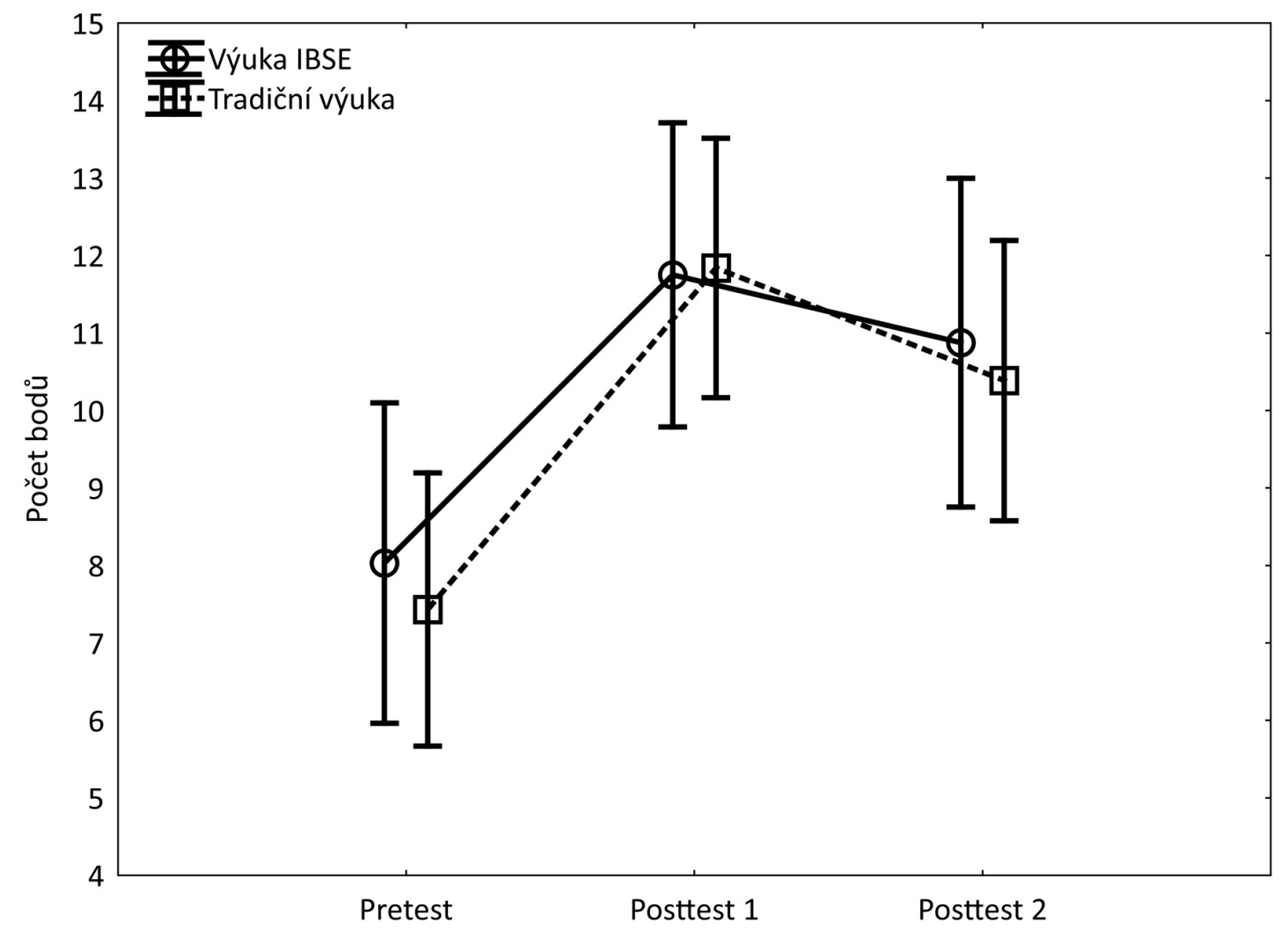

Obr. 1: Vývoj celkového skóre u žáků základních škol. Vliv opakování testu je statisticky průkazný $\left(p<10^{-6}\right)$. Vliv typu výuky průkazný není $(p=0,87)$. Znázorněny jsou průměry a $95 \%$ konfidenční interval

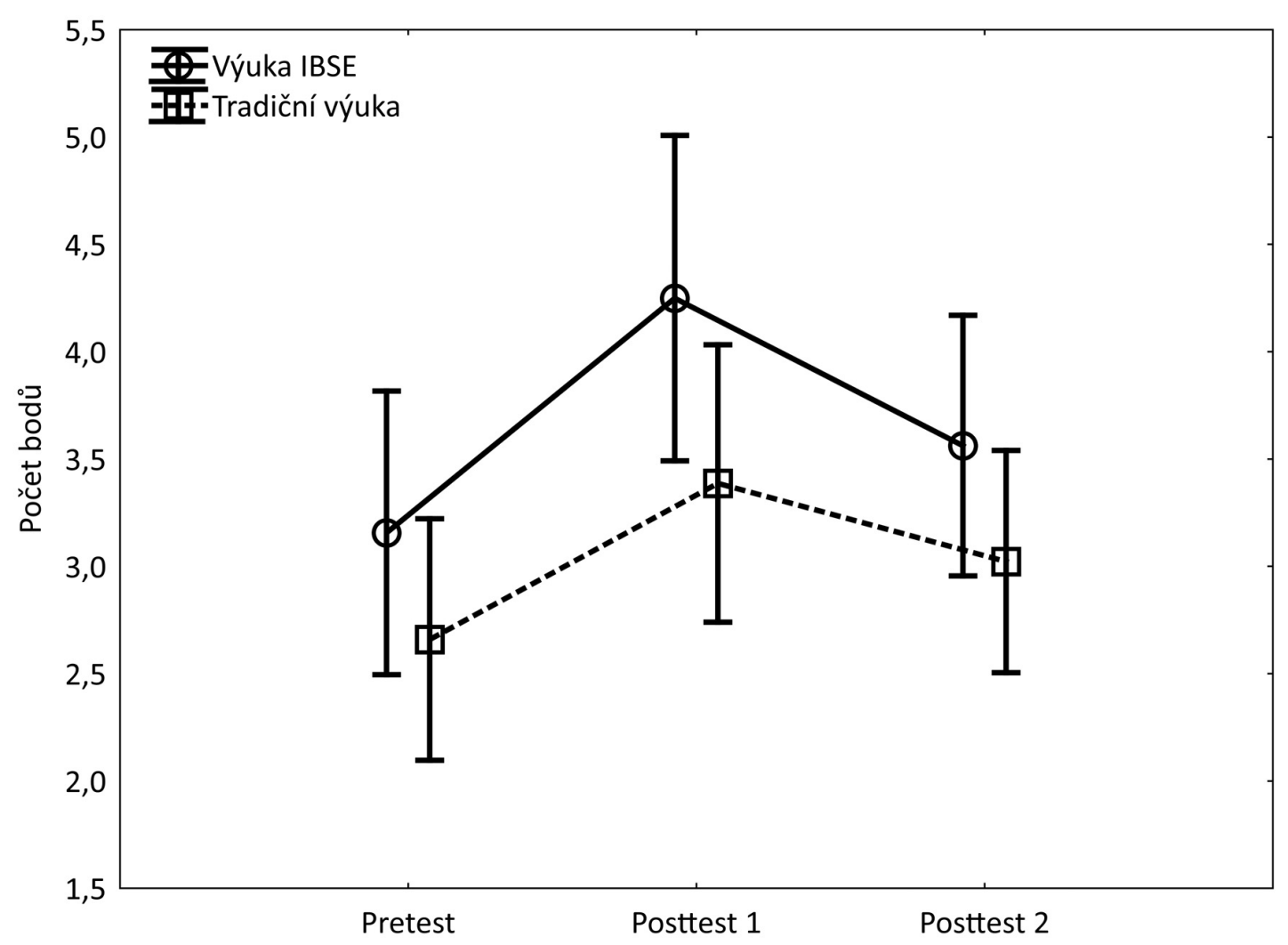

Obr. 2: Vývoj skóre ze znalostní části testu u žáků základních škol. Vliv opakování testu je statisticky průkazný $(p=0,004)$. Vliv typu výuky průkazný není $(p=0,48)$, ačkoli výraznější rozdíly jsou patrné u žáků s tradičním typem výuky. Znázorněny jsou průměry a $95 \%$ konfidenční interval 
Podobnější celkovému bodovému zisku byla část hodnocení, zabývající se získanými dovednostmi. Také zde se ukázal jako významný vliv opakování testu $\left(F_{2,70}=\right.$ $\left.=14,26 ; p<10^{-5}\right)$ a nevýznamný vliv typu výuky $\left(F_{2,70}=0,51 ; p=0,6\right)$. Počet bodů z dovednostní části se zvýšil ze 4,7 během pretestu na 8,03 v prvním posttestu, poté klesl na 7,3 v posttestu 2 (oba typy výuky; obr. 3).

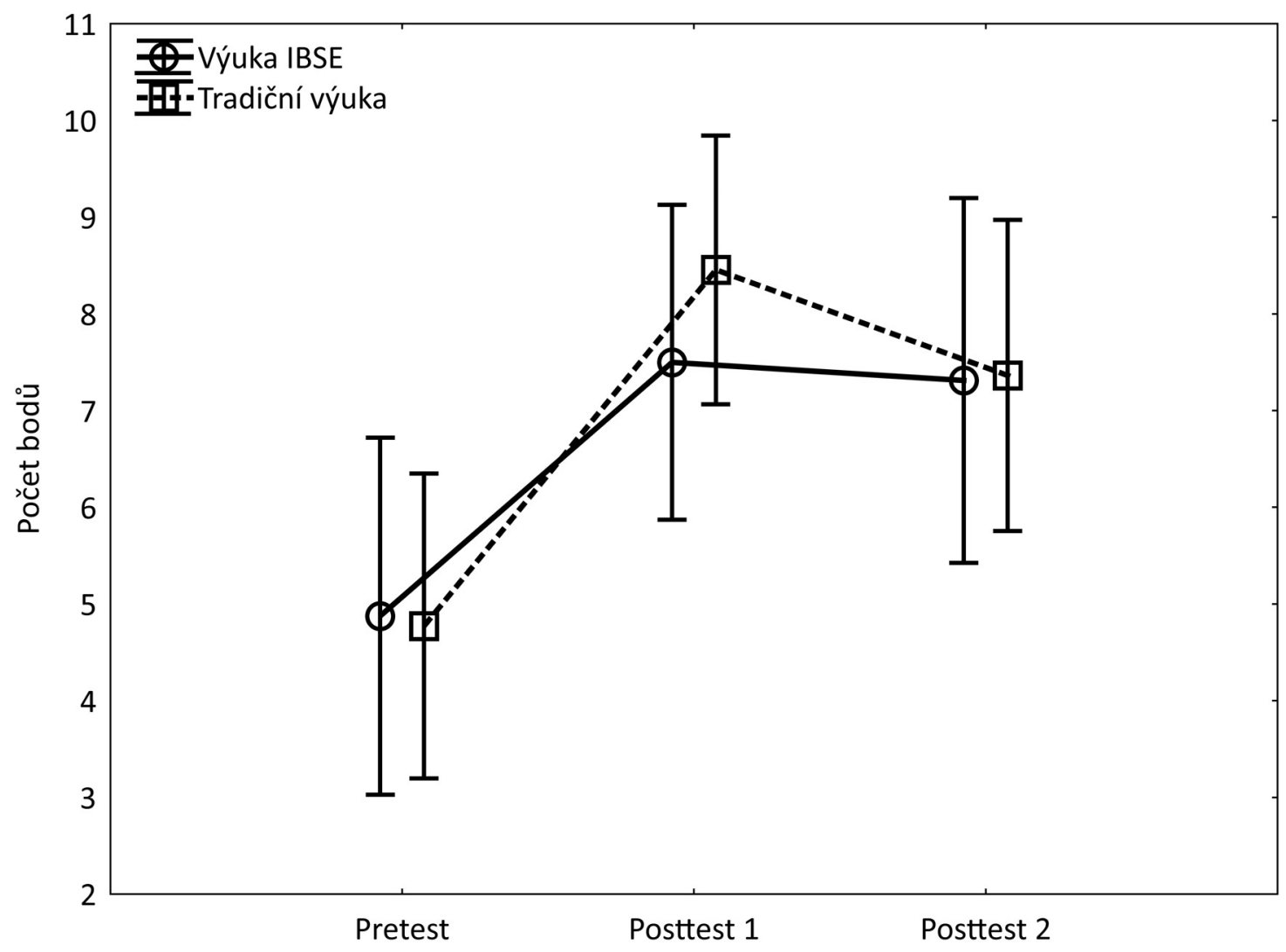

Obr. 3: Vývoj skóre z dovednostní části testu u žáků základních škol. Vliv opakování testu je statisticky významný $\left(p<10^{-5}\right)$. Vliv typu výuky průkazný není $(p=0,6)$, ačkoli menší pokles bodů mezi prvním a druhým posttestem nastal u žáků s tradičním typem výuky. Znázorněny jsou průměry a $95 \%$ konfidenční interval

\section{ŽÁCI VÍCELETÝCH GYMNÁZIÍ}

Odlišný obrázek od žáků základních škol skýtají žáci víceletých gymnázií. Při celkovém hodnocení se ukázal nejen významný vliv opakování testu $\left(F_{2,44}=5,08\right.$; $p=0,01)$, ale i typu výuky $\left(F_{2,44}=4,08 ; p=0,02\right)$. Statisticky významný vliv typu výuky se projevil především mezi pretestem a posttestem 1 , kde u experimentální skupiny došlo ke zlepšení o 4,1 bodu, zatímco u kontrolní skupiny bylo zlepšení pouze 0,6 bodu. Následný pokles během posttestu 2 byl již v obou skupinách srovnatelný (1,3 a 1,6 bodu; obr. 4).

Vliv typu výuky se neprokázal při vyhodnocení znalostní části testů $\left(F_{2,44}=0,68\right.$; $p=0,51)$. Vliv opakování testu byl, stejně jako $\mathrm{v}$ ostatních případech, statisticky průkazný $\left(F_{2,44}=28,26 ; p<10^{-7}\right)$. Kromě výrazného zlepšení mezi pretestem a posttestem 1 (ze 4,48 na 6,38 bodu) však nastalo i značné zhoršení v druhém posttestu na 4,2 bodu (oba typy výuky, obr. 5). 


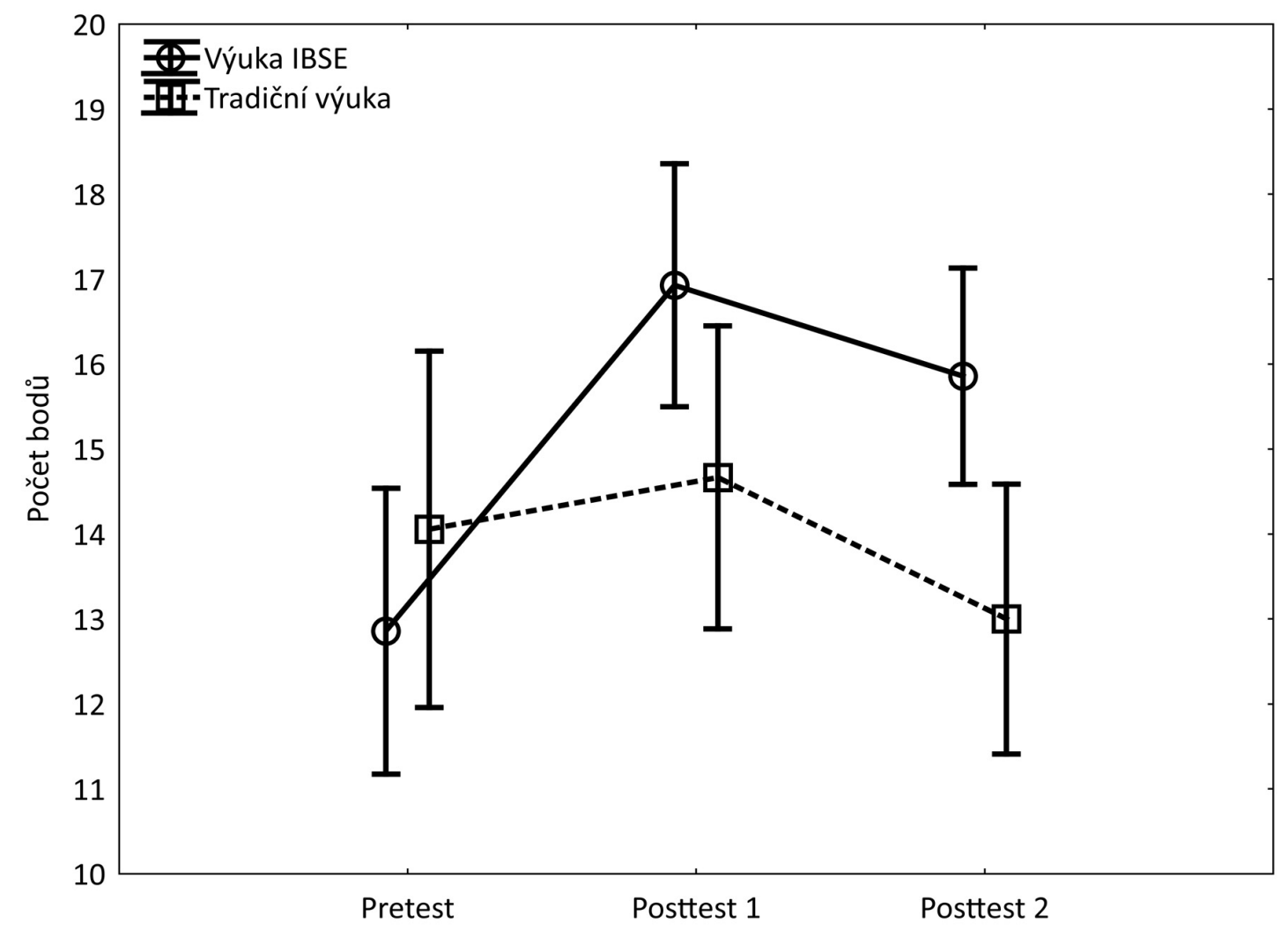

Obr. 4: Vývoj celkového skóre u žáků víceletých gymnázií. Vliv opakování testu je statisticky průkazný $(p=0,03)$, stejně tak i vliv typu výuky $(p=0,02)$. Velmi výrazný je především vliv typu výuky na nárůst znalostí mezi pretestem a posttestem 1 .

Znázorněny jsou průměry a $95 \%$ konfidenční interval

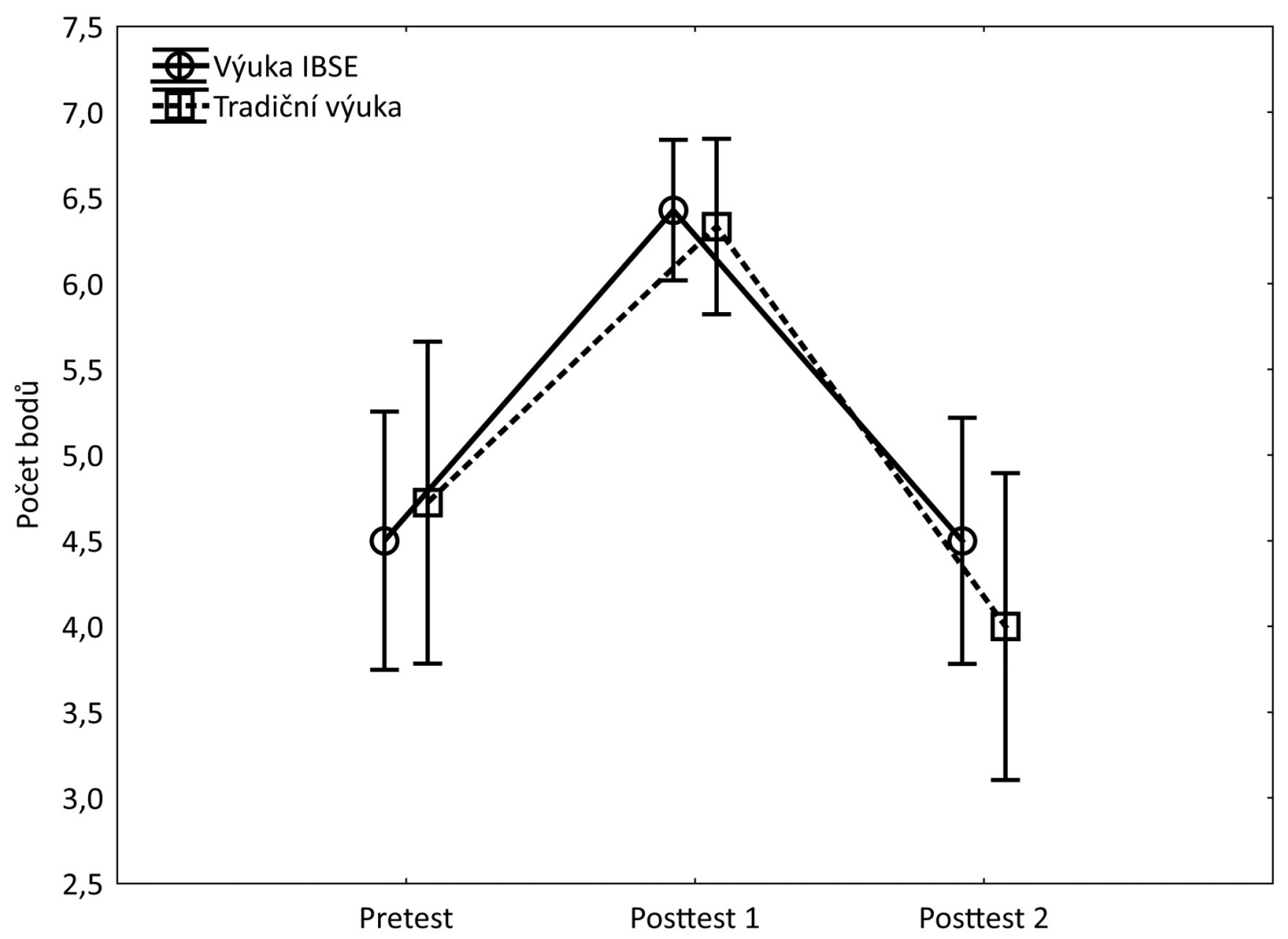

Obr. 5: Vývoj skóre ze znalostní části testu u žáků víceletých gymnázií. Žáci se významně zlepšili mezi pretestem a posttestem 1 a zhoršili mezi oběma posttesty (vliv opakování testu je významný, $\left.p<10^{-7}\right)$. Vliv typu výuky výsledky neovlivnil $(p=0,51)$. Znázorněny jsou průměry a $95 \%$ konfidenční interval 
Kvalitativně odlišná situace byla zaznamenána při analýze dovednostní části testu. Zatímco vliv opakování testu se zde ukázal jako neprůkazný $\left(F_{2,44}=1,77\right.$; $p=0,18)$, vliv typu výuky měl na dovednosti žáků víceletých gymnázií signifikantní vliv $\left(F_{2,44}=3,62 ; p=0,04\right)$. Rozdíl byl v celkovém trendu vývoje výše dovedností v závislosti na typu výuky - zatímco u žáků experimentální skupiny došlo k poměrně rovnoměrnému nárůstu z $8,4 \mathrm{v}$ pretestu na 10,4 a $11,2 \mathrm{v}$ posttestu $1 \mathrm{a} 2$, počet bodů žáků v kontrolní skupině fluktuoval kolem 9 ( $\pm 0,7$ bodu; obr. 6$)$.

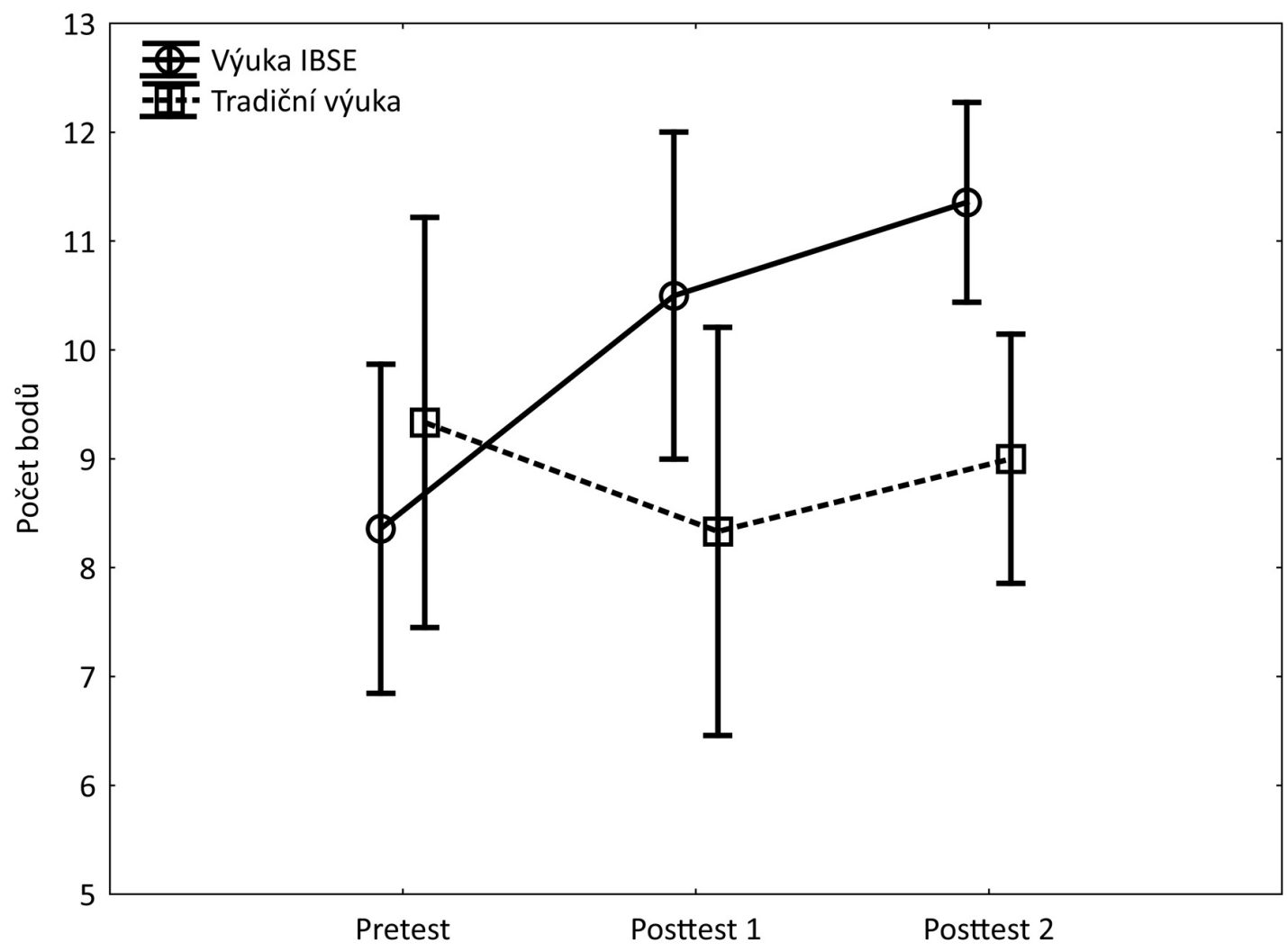

Obr. 6: Vývoj skóre z dovednostní části testu u žáků víceletých gymnázií. Z grafu je patrný postupný nárůst dovedností u žáků víceletých gymnázií s IBSE výukou a fluktuace výše osvojených dovedností u žáků s tradiční výukou. Vliv opakování testu se celkově neprojevil jako významný $(p=0,18)$, ale vliv typu výuky měl signifikantní efekt $(p=0,04)$. Znázorněny jsou průměry a $95 \%$ konfidenční interval

\section{DISKUSE}

Hlavním cílem tohoto výzkumu bylo zjistit, zda výuka s prvky badatelsky orientovaného vyučování vede k lepšímu osvojení znalostí a dovedností než klasické tradiční vyučování, při kterém žáci pracují podle návodu od učitele. Na základě získaných výsledků se ukázalo, že typ výuky měl signifikantní vliv na dovednosti žáků víceletých gymnázií. Mattheis a Nakayama (1988) došli ke stejnému závěru při svém výzkumu, kde program obsahující prvky IBSE v laboratorních cvičení zvýšil schopnosti žáků v př́rodovědných předmětech, zejména dovednosti spojené se sběrem a interpretací dat. IBSE nezajištuje výrazné zlepšení znalostí žáků a studentů (cf Rokos, 2015), ale umožňuje žákům osvojit si metodické postupy, které jim v budoucnu umožní samostatně řešit nové problémy. U žáků základní školy však tento trend nebyl pozorován, jelikož nebyl zjištěn signifikantní rozdíl mezi experimentální a kontrolní skupinou. Tento výsledek lze považovat za vhodný základ pro další výzkumy v budoucnu. Za prvé může být zpơsoben tím, že na gymnáziích jsou žáci s lepšími studijními výsledky, ale v tomto př́padě by IBSE mělo být určeno pro všechny žáky, nikoliv 
jen pro ty s lepšími výsledky. Možné vysvětlení může představovat typ práce využívaný na jednotlivých školách, kdy žáci gymnázia mohou být více zvyklí na činnosti podobné IBSE (samostatná práce, projekty, pokusy apod.). Výzkumy, které by porovnávaly žáky základní školy a víceletých gymnázií, v českých podmínkách bohužel chybějí, ale někteří autoři se zaměřili na sledování efektivity IBSE na vybraných edukačních stupních. Vácha a Ditrich (2016) zjistili, že výuka s prvky IBSE měla statisticky prokazatelný vliv na osvojování nových znalostí u žáků na primárním stupni základních škol. Autoři dodávají, že IBSE by mohlo mít za následek také pozitivnější vztah žáků $\mathrm{k}$ přírodovědným předmětům. Ke stejnému závěru dospěla také Nezvalová (2010), která uvádí, že aplikování prvků bádání do výuky pozitivně ovlivňuje osvojování nových poznatků a vědomostí. Vácha a Ditrich (2016) dále vyzdvihují nutnost častější aplikace prvků IBSE do výuky již na primárním stupni.

Ke stejnému pozitivnímu efektu IBSE dospěly ve své studii Ryplová a Reháková (2011). U žáků sedmého ročníku v rámci výuky environmentální výchovy zjistily, že žáci, kteří absolvovali program s prvky badatelsky orientovaného vyučování, dosahovali poté v didaktickém testu většinou lepších výsledků než žáci, kteří absolvovali klasickou frontální výuku bez prvků bádání.

Závěry výše popsané studie provedené u žáků víceletého gymnázia jsou velmi podobné s výsledky výzkumu Coberna et al. (2010), kteří provedli podobnou studii v oblasti přírodních věd se žáky na vybraných amerických středních školách. Cobern et al. (2010) ukázali, že badatelsky orientované vyučování a klasické vyučování vedou k osvojení srovnatelného množství vědomostí, nicméně důležitou roli hraje osvojení si tzv. badatelských dovedností. Žáci se naučili lépe navrhovat vlastní pokusy, brali v potaz různé proměnné a interpretovali svá data. Na druhou stranu se tyto závěry liší od výsledků výzkumu Changa a Maoa (1999), kteří zjistili, že studenti pracující badatelským způsobem dosáhli podstatně vyšších výsledků než studenti z kontrolní skupiny pracující klasickým zpo̊sobem.

Do budoucna by bylo vhodné podpořit zjištěné závěry dalšími průzkumy a také se zaměřit na fakt, zda žáci na nižším cyklu víceletého gymnázia pracují odlišným způsobem než žáci na vyšším stupni základní školy, což by mohlo ožrejmit, proč u žáků gymnázia mělo IBSE signifikantní vliv na rozvoj jejich badatelských dovedností. Zároveň je také nutno vzít v potaz, že rozdíl mezi úrovní osvojení znalostní a dovedností mohl být $\mathrm{v}$ této studii také způsoben tím, že v pretestech a posttestech byly znalostní otázky vždy uzavřeného typu, zatímco dovednostní otázky byly otevřené a dávaly tak žákům větší možnost projevu, a tím i zisku více bodů.

\section{ZÁVĚR}

Cílem této studie bylo zjistit, zda badatelsky orientovaná výuka vede k lepšímu osvojení vědomostí a rozvoji badatelských dovedností než klasické vyučování při laboratorních pracích, kde žáci pracují podle předem stanoveného postupu. Pomocí pretestu a dvou posttesti̊ bylo provedeno srovnání vlivu typu výuky na výsledky žáků na základní škole a nižším cyklu osmiletého gymnázia. Výsledky výzkumu ukázaly, že u žáků základních škol nenastal signifikantní rozdíl v závislosti na typu výuky. Opačná situace nastala u žáků víceletých gymnázií, kde výuka s prvky badatelsky orientovaného vyučování vedla k signifikantně lepším výsledkům žáků. Ve znalostní části testu nebyl u žáků víceletého gymnázia pozorován výrazný rozdíl, ale u dovednostní části testu bylo zjištěno, že výuka s prvky IBSE má výrazný vliv na úroveň badatelských dovedností žáků. 


\section{PODĚKOVÁNí}

Tento příspěvek vznikl za finanční podpory projektu GAJU 118/2016/S.

\section{LITERATURA}

Anderson, R. (2002). Reforming science teaching: What research says about inquiry. Journal of Science Teacher Education, 13(1), 1-12.

Banchi, H. \& Bell, R. (2008). The many levels of inquiry. Dostupné z http://www.miseagrant.umich.edu/lessons/files/2013/05/The-Many-Levels-of-InquiryNSTA-article.pdf

Bell, R., Smetana, L. \& Binns, I. (2005). Simplifying inquiry instruction. The Science Teacher, 72(7), 30-34.

Bhattacharyya, S., Volk, T. \& Lumpe, A. (2009). The influence of an extensive inquiry-based field experience on pre-service elementary student teachers' science teaching beliefs. Journal of Science Teacher Education, 20, 199-218.

Bunterm, T., Lee, K., Kong, J. N. L., Srikoon, S., Vangpoomyai, P., Rattanavongsa, J. \& Rachahoon, G. (2014). Do different levels of inquiry lead to different learning outcomes? A comparison between guided and structured inquiry. International Journal of Science Education, 36(12), 1937-1959.

Cobern, W. W., Schuster, D., Adams, B., Applegate, B., Skjold, B., \& Undreiu, A. (2010). Experimental comparison of inquiry and direct instruction in science. Research In Science \& Technological Education, 28(1), 81-96.

Dostál, J. (2013). Badatelsky orientovaná výuka jako trend soudobého vzdělávání. E-pedagogium, 2013(III), 81-93.

Eastwell, P. (2009). Inquiry learning: Elements of confusion and frustration. The American Biology Teacher, 5(1), 263-264.

Education development center. (2007). Inquiry-based science instruction and students' science content knowledge: A research synthesis. Paper presented at the annual meeting of the National Association for Research in Science Teaching, New Orleans.

Einsiedler, W. (2000). Von Erzieungs- und Unterrichtsstilen zur Unterrichtsqualität. In M. K. W. Schweer (Eds.), Lehrer-Schüler-Interaktion (109-128). Opladen:

Leske + Budrich.

Chang, Ch.-Y. \& MAO, S-L. (1999). Comparison of Taiwan science students' outcomes with inquiry-group versus traditional instruction. The Journal of Educational Research, 92(6), 340-346.

Janík, T. et al. (2013). Kvalita (ve) vzdělávání: obsahově zaměřný př́stup ke zkoumání a zlepšování výuky. Brno: Masarykova univerzita.

Johnson, A. D. (2009). 40 inquiry exercises for the College Biology Lab. Arlington: VA, NSTA Press.

Ketelhut, D. J. (2007). The impact of student self-efficacy on scientific inquiry skills: An exploratory investigation in River City, a multi-user virtual environment. Journal of Science Education and Technology, 16(1), 99-111.

Kulič, V. (1980). Některá kritéria efektivity učení a vyučování a metody jejího zjištování. Pedagogika, 30(6), 677-698. 
Mattheis, F.E. \& Nakayama, G. (1988). Effects of a laboratory-centered inquiry program on laboratory skills, science process skills, and understanding of science knowledge in middle grades studens. Dostupné z http://files.eric.ed.gov/fulltext/ED307148.pdf

Minner, D. D., Levy, A. J. \& Century, J. (2010). Inquiry-Based Science Instruction What is it and does it matter? Results from a research synthesis years 1984 to 2002 . Journal of Research in Science Teaching, 47(4), 474-496.

Nezvalová, D. (2010). Inovace v př́rodovědném vzdělávání. Olomouc: Univerzita Palackého v Olomouci. Dostupné z http://zvyp.upol.cz/publikace/nezvalova1.pdf

Papáček, M. (2010, březen). Limity a šance zavádění badatelsky orientovaného vyučování přírodopisu a biologie v České republice. In M. Papáček (Ed.), Didaktika biologie v České republice 2010 a badatelsky orientované vyučování (145-162). České Budějovice: Jihočeská univerzita v Českých Budějovicích.

Petr, J. (2014). Možnosti využití úloh z biologické olympiády ve výuce přírodopisu a biologie: inspirace pro badatelsky orientované vyučování. Ceské Budějovice: Jihočeská univerzita v Českých Budějovicích.

Petr, J., Ditrich, T., Závodská, R. \& Papáček, M. (2015). Inquiry based biology education in the Czech Republic: A reflection of five years dissemination. In K. Maaß, B. Barzel, G. Törner, D. Wernish, D. Schäfer \& K. Reiz-Konzebovski (Eds.), Education the Educators: International Approaches to Scaling-up Professional Development in Mathematic and Science Education (118-124). [Proceedings of the Conference hosted jointly by the project mascil (mathematics and science for life) and the German Centre for Mathematics Education (DZLM), 15-16 December 2014 in Essen, Germany.] Münster: WTM - Verlag für wissenschaftliche Texte und Medien.

Petty, G. (2013). Moderní vyučování. Praha: Portál.

Proconet (2011). Towards Europe 2020: Implementation of inquiry-based science teaching/education. Freiburg: ProCoNet.

Průcha, J. (1996). Pedagogická evaluace. Brno: Masarykova Univerzita.

Rocard, M., Csermely, P., Jorde, D., Lenzen, D., Walberg-henriksson, H. \& Hemmo, V. (2007). Science education now: A renewed pedagogy for the future of Europe. Brussels:

European Commission, Directorate-General for Research, Information and Communication Unit. Dostupné z http://ec.europa.eu/research/sciencesociety/document_library/pdf_06/report-rocardon-science-education_en.pdf

Rokos, L. (2015, srpen). Assessment of inquiry-based science teaching in biology education. Poster prezentovaný na 11. konferenci European Science Education Research Association, Helsinki.

Ryplová, R. \& Reháková, J. (2011). Přínos badatelsky orientovaného vyučování (BOV) pro environemntální výchovu: Př́padová studie implementace BOV do výuky na ZS̆. Envigogika, 6(3), 1-9.

Seidel, T. \& Shavelson, R. J. (2007). Teaching effectiveness research in the past decade: The role of theory and research design in disentangling meta-analysis results. Review of Educational Research, 77(4), 454-499.

Scheerens, J. (2004). Review of school and instructional effectiveness research. Paper commissioned for the EFA Global Monitoring Report 2005, The quality imperative, UNESCO.

Schwartz, R.S., Lederman, N., Khishfe, R., Lederman, J. S., Matthews, L., \& Liu, S. (2002). Explicit-reflective instructional attention to nature of science and scientific 
inquiry: Impact on student learning. Paper presented at the 2002 annual international conference of the association for the education of teachers in science, Charlotte, NC.

Starý, J. \& Chvál, M. (2009). Kvalita a efektivita výuky: metodologické přístupy. In M. Janíková \& K. Vlčková (Eds.), Výzkum výuky: tematické oblasti, výzkumné př́stupy a metody. Brno: Paido.

Stavik-karlsen, G. \& Gray, P. (2013). S-TEAM in the mirror: Evidence, quality and relevance in inquiry-based science teaching. In M. H. Hoveid \& P. Gray (Eds.), Inquiry in science education and science teacher education: research on teaching and learning through inquiry based approaches in science (teacher) education (278-304). Trondheim: Akademika.

Stuchlíková, I. (2010). O badatelsky orientovaném vyučování. In M. Papáček (Ed.), Didaktika biologie v České republice 2010 a badatelsky orientované vyučování (129-135). Ceské Budějovice: Jihočeská univerzita v Českých Budějovicích.

Škoda, J., Doulík, P., Bílek, M. \& Šimonová, I. (2015). The efficiency of inquiry-based science instruction in relation to the learners' motivation types. Journal of Baltic Science Education, 14(6), 791-803.

Vácha, Z. \& Ditrich, T. (2016). Efektivita badatelsky orientovaného vyučování na primárním stupni základních škol v přírodovědném vzdělávání v Ceské republice s využitím prostředí školních zahrad. Scientia in Educatione, 7(1), 65-79.

Wilson, C. D., Taylor, J. A., Kowalski, S. M. \& Carlson, J. (2010). The relative effects and equity of inquiry-based and commonplace science teaching on students ${ }^{6}$ knowledge, reasoning, and argumentation. Journal of Research in Science Teaching, 47(3), 276-301.

LUKÁŠ RokOs, Lrokos@pf.jcu.cz

VlADISLAVA VomÁČKOVÁ, vladka.vomackova@seznam.cz

Jihočeská univerzita v Českých Budějovicích, Pedagogická fakulta

Katedra biologie

Jeronýmova 10, Ceské Budějovice, Ceská republika 